Arab World English Journal (AWEJ) Volume 12. Number1 March 2021

DOI: https://dx.doi.org/10.24093/awej/vol12no1.12

Pp. $165-180$

\title{
Learning to Present in English: Exploring the Voices of Preparatory-Year Female Undergraduates in Saudi Arabia
}

\author{
Noura Ali Alghamdi \\ English Language Institute, University of Jeddah \\ Faysaleyya Campus, Jeddah, Saudi Arabia \\ Email: naalghmadi@uj.edu.sa
}

Received: $10 / 28 / 2020$

Acceoted: 1/27/2021

Published:3/24/2021

\begin{abstract}
This study examines how a group of students enrolled in preparatory year program at a Saudi university describe their experiences while engaging with a specific literacy event, i.e. oral presentations in an English as a Foreign Language classroom. It adopts a case study methodology that relies on qualitative data-collection techniques, including reflections written by female undergraduates, informal conversations with these undergraduates, observational fieldnotes of classroom activities and a research journal. Relying on a social understanding of literacy, collected data are thematically analysed to examine how students view their experiences in this academic literacy event. Three major themes are highlighted in this study in relation to students' experiences with this event: topic choice, fear and anxiety and the gains and losses associated with learning to prepare and make short presentations in English. Discussion sheds light on the impact of these experiences on the identity positions that learners develop and negotiate to participate in this event. It also highlights some of the challenges that mediate students' experiences in this event and how they recognize and address these challenges. The study draws attention to the need for more indepth, qualitative research to examine academic literacy events in tertiary education in which learners' voices are brought to light to explore the situated nature of learning and its impact on learners.

Keywords: EFL classrooms, oral presentations, preparatory year, qualitative case study, Saudi university students, social practices, speaking skill
\end{abstract}

Cite as: Alghamdi, N. A, . (2021). Learning to Present in English: Exploring the Voices of Preparatory-Year Female Undergraduates in Saudi Arabia. Arab World English Journal, 12 (1) 165-180. DOI: https://dx.doi.org/10.24093/awej/vol12no1.12 


\section{Introduction}

As "a university initial stage aimed at preparing students academically, socially, psychologically and culturally" (Alghamdi, 2015, p. 118), a preparatory year program (PYP) is offered to high-school graduates upon their joining the university. It is expected to bridge the gap between secondary school education and tertiary education and provide students with the necessary skills needed for university study. Most universities in Saudi Arabia adopt PYPs in which teaching English language represents a highly-prioritized component as in the university where this study takes place. While there is usually an extensive, year-long course that focuses on teaching English, other subjects are often taught in English as well, such as chemistry and physics. English is, furthermore, prioritized for undergraduate learners who intend to major in departments in which English is the main medium of instruction, such as medicine, engineering and computer sciences. In the context of this study, the use of an integrated-skill curriculum to teach English is supported by introducing students to various opportunities to learn about essential study skills. Among these skills comes the regular use of oral presentations to improve the speaking skill among students while training them to search for information, organize ideas and communicate effectively. This study explores university learners' voices as they describe and reflect upon their experiences with oral presentations. These voices are investigated to consider how engaging with oral presentations in an English as a Foreign Language (EFL) classroom impacts learners and shape their views of language learning and themselves.

\section{Literature Review}

Oral presentations have not received adequate attention within research on English language teaching and learning, especially in relation to undergraduates in Saudi Arabia despite the fact that they represent a common academic genre whose value has been acknowledged among academic researchers. According to Morita (2000), oral presentations can be used as one of the tools to socialize learners into disciplinary knowledge and practices. The use of oral presentations can also offer significant opportunities to learners to represent and communicate their developing knowledge and expertise in tertiary education (Hyland, 2009). In relation to language learning, the use of oral presentations can help improve how oral communication is taught among graduate and undergraduate learners (Zareva, 2011).

With the growing reliance in Saudi universities on using English as the main medium of instruction, academic interests in researching English language use is growing rapidly. An increasingly growing body of research is directed towards oral communication (e.g., Al-Mohanna, 2011; Daif-Allah \& Khan, 2016; Mousawa \& Elyas, 2015). Available research tends to focus on examining problems that surround speaking. Al-Mohanna (2011), for example, examines aspects of classroom interaction which negatively impact the development of oral communication among university learners. Alqahtani (2015) investigates the difficulties faced by Saudi language learners that surrounds their willingness to learn English. Rafada and Madini (2017) study speaking-related anxiety in English language university classrooms. Abker (2020) uses oral recorded tests to examine the problems that university Saudi EFL learners face when pronouncing English morphemes. In addition, other studies seek to highlight language learners' practices that underlie their speaking. Ababneh (2016), for example, uses survey data to investigate the literacy skills and practices in English and Arabic among female undergraduates through survey data. Gaffas (2019) explores the impact of specialized language teaching on academic language development. 
In relation to research methodologies, quantitative methods which rely on questionnaires and surveys are commonly employed in language research within the Saudi context (e.g., AlKhotaba, Alkhataba, Abdul-Hamid \& Bashir, 2019; Alqahtani, 2015; Alrasheedi, 2020; Eissa, 2019; Javid, Al-Asmari, \& Farooq, 2012, Soomro \& Farooq, 2018). Qualitative methods, in contrast, do not seem to be similarly popular. Exceptions include Mahboob and Elyas (2014) who look for linguistic and visual indications of a Saudi variety of English and they support their textually-based analysis by consulting linguists and experienced Saudi teachers of English. Barnawi and Phan (2015) employ a qualitative case study approach to understand how two Western-trained Saudi TESOL male language teachers utilize their training to teach English and the effect of their use on issues related to knowledge construction and pedagogical practices. Ababneh (2016) uses research notes and observations in combination with two questionnaires to explore the literacy skills and practices of these undergraduates. Daif-Allah and Khan (2016) investigate the needs of language majors in a Saudi college through survey questionnaires, semistructured interviews and a speaking test. Nazim and Hazarika (2017) use qualitative and quantitative methods to examine how 40 teachers in a Saudi university perceive learners' linguistic proficiency in relation to ESP standards. Gaffas (2019) relies on a case study approach in which questionnaires, interviews and group discussions are employed to explore the development of academic language.

This over-reliance on quantitative methods has lead to a situation in which in-depth examination of learners' voices to highlight their experiences still remains an under-researched area in the Saudi context. This study attempts to address this gap through providing a platform for highlighting learners' voices and experiences. It aims to answer the following research questions: 1- What are the social practices that surround female undergraduate students' engagement in oral presentations in a preparatory-year English as a Foreign Language course? 2- How do these students describe their experiences with these practices and how they impact their views of themselves? 3- What are the challenges faced by these students and how do they address these challenges?

\section{Theoretical Framework}

A social account of literacy is adopted in this study to address the research questions and explore what literacy (or reading and writing) means for learners and how it is used (Barton, 1994; Barton \& Hamilton, 1998; Street, 1984; Pahl \& Rowsell, 2012). Social accounts of literacy, promoted by the New Literacy Studies (NLS) view literacy as "an activity, located in the space between thought and text" (Barton \& Hamilton, 1998, p. 3). This understanding of literacy moves beyond the functional, decontextualized value of reading and writing to focus on what literacy means for people and how it is used. Investigating the situated nature of literacy is important because it allows researchers to explore relevant issues which shape and impact language learning. For this study, two issues are particularly significant: learning strategies and identity construction. Learning strategies refer to the actions which learners employ to facilitate their learning (Oxford, 1999). Issues of identity construction, on the other hand, are concerned with the identity positions which students negotiate while preparing and making their presentations. Identity is seen here as "how a person understands his or her relationship to the world, how that relationship is constructed across time and space, and how the person understands possibilities for the future" (Norton, 2013, p. 4). 
Two analytic concepts are frequently identified within NLS: literacy events and literacy practices. While literacy events refer to "any occasion in which a piece of writing is integral to the nature of the participants' interactions and their interpretative processes" (Heath, 1983, p. 50), literacy practices refer to "the general cultural ways of utilising written language which people draw upon in their lives" (Barton \& Hamilton, 2005, p. 7). Literacy practices are inferred from the way people engage with these events as they "are shaped by social institutions and power structures, and influenced by nonvisible elements, including social relationships, values, ways of thinking, skills, and structured routines and pathways" (Matusiak, 2013, p. 1579). Literacy practices can be examined through the use of qualitative data collection techniques which include "observation of the practices surrounding the production of texts - rather than focusing solely on written texts - as well as participants' perspectives on the texts and practices" (Lillis \& Scott, 2008, p. 11).

\section{Methods}

\subsection{Data Collection Tools}

To conduct this study, an ethnographically-oriented qualitative research approach was used using reflections written by undergraduate students, informal conversations with these students, observational fieldnotes of classroom activities and a research journal. Although participants were asked to write their reflections, thoughts and views regarding specific points, such as how they chose their topics, how they prepared their presentations and the challenges they faced, these reflections are treated as diaries because of their revealing nature. According to Bailey (1991), a diary refers to "a first-person account of a language learning or teaching experience, documented through regular, candid entries in a personal journal and then analysed for recurring patterns or salient events" (p. 215). Written reflections and thoughts represent a significant research tool in language research because they provide room for learners' voices and views (Nunan, 1992). In this study, students were invited to write down their thoughts and reflections after each presentation. Because participation was voluntary, only some of the thirty-six students enrolled in this course have chosen to participate and hand in their reflections which they were asked to write anonymously to encourage them to express their opinions freely. Students were asked to use the language they prefer. While some have chosen to rely on a mixture of Arabic and English, many seemed to prefer Arabic and only few relied totally on English to write their reflections. To gain further insight into students' engagement with this task, observational fieldnotes of classroom activities related to this event and a research journal were used to maintain "ideas, reflections, thoughts, actions, reactions, conversations and so on" which are significant for this investigation (Thomas, 2011, p. 164). Short, informal conversations were also used throughout the academic semester to ask students about different aspects of their experiences with these presentations.

\subsection{Participants}

This study takes place in a university in which the English language curriculum represents a mandatory element in its PYP. The literacy event under investigation is concerned with short oral presentations (or speaking tasks as they are often called in this context) which represent an essential part of the portfolio assessment policy used in this EFL course. In these oral presentations, students are asked to give a small talk that ranges from $2-3$ minutes discussing specific topics, assigned by the teacher. Students were expected to avoid repeating the specific details of their talks. For example, when they were asked to speak about their dream jobs, students were required 
to ensure that they had chosen different jobs to speak about or that they had avoided repeating or sharing details from each other in their presentations.

For this event, there were three presentations, distributed in the second, fifth and eighth week in the academic semester that lasted for around fourteen weeks (Table one). While the first two presentations were carried out in regular face-to-face classes, the third task was carried out after the suspension of face-to-face education due to the coronavirus shut down. The third presentation was taught through Blackboard which was the established electronic system adopted in the university in which this study took place. As some students were still adapting to distant education and others were complaining of poor internet connections, many sent their recorded presentations to the teacher via WhatsApp.

Table one: Presentation topics and study participants

\begin{tabular}{llll}
\hline Week & Task & Topic & Number of Participants \\
\hline 2 & 1 & $\begin{array}{l}\text { Present a review of a popular } \\
\text { performer. }\end{array}$ & 24 \\
\hline 5 & 2 & What is your dream job? & 20 \\
\hline 8 & 3 & $\begin{array}{l}\text { Prepare an oral news report } \\
\text { about a fictional or real event. }\end{array}$ & 15 \\
\end{tabular}

In relation to the speaking skill, students had other ungraded opportunities to practice this skill in the course. These opportunities appeared in different exercises included in their textbooks in which students were asked to speak about specific topics in their textbooks or construct dialogues to practice using assigned vocabulary items or grammatical rules.

\subsection{Engaging with Oral Presentations}

Each oral presentation was introduced through a PowerPoint slideshow with a discussion of what students needed to do and the timeframe that they needed to adhere to. Other significant issues were additionally highlighted in this introductory discussion such as, the assessment criteria, use of supporting materials, appropriate vocabulary and grammatical rules, good organization and effective presentation skills. Students were asked to coordinate with each other to ensure that no two students shared the same topic. If two students, however, chose one topic, each was expected to make her presentation different from the other. Considering the efforts needed to fulfil such expectation and the fact that many students worked in pairs or groups on their presentations, most students seemed to prefer to search for totally different topics to avoid the risk of not being able to fulfil that expectation.

Students usually discussed in pairs or groups their topics to start brainstorming for ideas. According to the official documents sent to teachers before each presentation, teachers were expected to spend 1-2 hours on explaining the presentation and guiding students in class. Students were usually given 2-3 days to prepare their presentations. Some students wrote down their ideas and asked for feedback from the teacher either in class, during office hours or via email while other 
students appeared to prefer working individually on their presentations without seeking advice or help from the teacher. A specific day was usually assigned for these presentations and students were not usually given another opportunity to present if they missed presenting on the assigned day without an acceptable excuse.

\section{Findings}

This section considers some of the aspects that shaped students' engagement with this literacy event and were highlighted within the collected data in general and participants' reflections in specific. The analysis starts first by looking at how students approached oral presentations while preparing and making them. After that, three of the significant themes that were highlighted in learners' reflections are discussed. These include topic choice, fear and anxiety and finally the gains and losses that students associated with participating in this event.

\subsection{Approaching the task}

When oral presentations were introduced, students were divided into groups to discuss how to prepare for their presentations. choose topics and search for ideas. Initial feelings among students in class appeared to be directly connected to how they described their English language skills. While some expressed their worries and concerns around their ability to present in English, others did not seem to be equally concerned. Few of these students even described how eager they were to present. There were many reasons for these positive feelings. Some, for example, described how they enjoyed speaking in English. Others described speaking tasks as a getaway from other classroom activities which they described as 'boring' such as grammar exercises and reading activities.

Despite repeated calls for learners to speak in English, discussions among students in class while brainstorming were often carried out in Arabic, i.e. learners' first language. Arabic seemed to be used as a strategic technique to mitigate the difficulties learners faced, considering the limited time available to work on these presentations in class. This was specifically true for those struggling with communicating in English. For these students, English was a must during assessed activities while in-class, side discussions among each other were flexible because they were not always monitored by the teacher and they were not graded. Arabic, thus, appeared as a more convenient option for these students.

Use of Arabic surfaced repeatedly in students' accounts of their experiences in different stages of preparation. The extent of relying on Arabic beyond those early discussions differed among students. Some students worked to search for specific words or sentences in Arabic first while few seemed to construct the whole speaking text in Arabic first before translating it into English using automated translation services, such as Google Translate. The practice of writing down the task in Arabic first was not evident in class during the first speaking task. It became clearly observable during the second task in which extra time was dedicated to work on the presentation in class to address learners' questions and help them prepare. They asked about parts of their Arabic texts to check if the offered information was enough. They also asked how they could say a specific word or phrase in English. Despite repeated attempts to encourage students and assist them to divide the task into smaller segments and construct them in English immediately, many complained that they did not know how to construct a complete text in English. Though they 
could manage individual exercises, they did not think that constructing a complete presentation on their own in English was an achievable task. These described the process of searching for the information and writing it down in Arabic first as a safe way to ensure their ability to make their presentations as required.

For these students, writing their work in Arabic first did not necessarily make the job easier despite their belief that Arabic offered them a way to manage and facilitate their work. These students were left with the responsibility of creating a complete Arabic text, changing the content into English and practicing it within 2-3 days. The change into English was not a smooth and straightforward process since students needed to ensure that their vocabulary choices and grammatical structures were accurate. This was specifically true for those who relied on online automated translation which was not always precise or accurate in relation to linguistic accuracy. They also needed to pay attention to issues, such as accurate pronunciation and effective presentation skills. One student complained after the first speaking task that

$$
\begin{aligned}
& \text { لا يوجد وقت كافي لكتابة الـ speaking و التحضير لله لأنها تحتاج إلى قراءة و جمع المعلومات و ترتيب الأفكار و }
\end{aligned}
$$

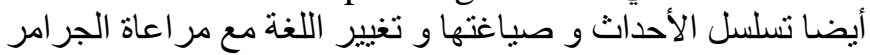

there is not enough time to write down the speaking and prepare for it because it requires reading and collecting information and organizing ideas and also sequencing the events and verbalizing them and changing the language while paying attention to grammar

Advanced speakers, on the other hand, faced a different challenge. Despite the fact that these students often seemed confident enough in class that they were able to speak successfully about any topic, their language skills did not always lead to the expected levels of performance that reflected their levels as their overall grades were not necessarily better than other students. As these students were sure that their linguistic skills gave them an advantage in this task, many of them did not seem to pay attention to the required instructions. Few even proudly spoke in class about how the tasks were too easy and did not need much preparation or practice at home. Common mistakes among these students included falling short of the required time, presenting without adequate practice ahead, performing with poor presentation skills or failing to discuss the required elements. Although their speaking abilities were usually impressive, such mistakes negatively impacted their assessment because they represented violations of the requirements and expectations explained to them earlier. These students seemed to rely on a socially common belief that advanced speaking skills in English represented a guarantee of their success in any language class. They believed that these abilities were sufficient enough to exempt them from the need to follow the task instructions as long as they were able to speak fluently in English.

In contrast, attention to instructions, expectations and requirements appeared to be a priority among other students whose language skills were not similarly advanced. To enhance their participation in these tasks and attain positive feedback and assessment, these students appeared to exert extra efforts to pay attention to all of these aspects. Many of these students, for example, talked about practicing their presentations repeatedly in front of their friends and family members or audio taping themselves while speaking to ensure that they covered the 2-3 minute timeframe and addressed all the necessary aspects. Many also described the efforts they exerted to make these 
presentations through consulting the teacher, classmates and family members regarding issues such as, pronunciation, grammar, vocabulary and creating smooth presentations.

\subsection{Topic Choice}

Many factors appeared to shape how students chose their topics. Personal interests represented a major factor. Availability of information in relation to language demands was also important. If a topic seemed to be challenging to research and speak about, students often chose another topic that was easier to approach and manage. It was not uncommon to hear students in class asking if it was OK for two students to speak about the same topic. Because students were warned against copying details of their topics from each other, most students worked to coordinate with each other to ensure that different topics were chosen. While most students did not seem to be bothered by this requirement in class, especially those who managed to inform others of their choices early, topic choice, however, surfaced as a challenging aspect of this event for some students. Despite the fact that students appeared to had chosen the topics they wanted, few used their reflections to highlight their dissatisfaction with their choices.

These students complained that the topics they wanted to speak about were already taken. They highlighted their frustration that their presentations did not really reflect what they wanted to speak about and how they could not think of unique details to make their presentations different from each other. One student wrote

$$
\text { كنت بأكتب عن الطب ، الجر احة ، بس أخذتها واحدة قبلي فاضطريت أختار شي ثاني }
$$

I was going to write about medicine, surgery. but another student took the topic before me so I had to choose something else

Another student expressed her disappointment that she could not talk about what she considered to be her dream job:

$$
\text { قلى بالي و لار هرة المهنة لأنه لم يتبق وظائف أخرى لكنني أردت أن أصبح ممرضة. تحدثت عن وظيفة لم تخطر }
$$

I chose this job because there were no other jobs left. I wanted to be a nurse. I spoke about a job that I have never thought about before, not even once.

This inability to choose the topics they wanted and their worries that they could risk their grades if they insisted on choosing similar topics appeared in their reflections as a considerably resentful attitude towards being forced to speak about topics that did not really reflect their dream jobs or favourite artists. For these students, the issue was not only about working on a task to improve their speaking in English. It was equally related to their personal interests and what they could share with others about themselves. One student considered that situation as one of the challenges that she faced while making her presentation because

$$
\text { لا يمكن تكرار الوظيفة التي أريدها حتى و إن كانت وظيفة أحلامي }
$$

repeating the job that I want is not permissible even if it is my dream job

Though these students generally managed to prepare and make their presentations, their inability to maintain control of their topics shaped their views of themselves as being caught in an unfair 
situation in which, unlike their classmates, they spoke about topics that they did not willingly choose.

\subsection{Fear and Anxiety}

Fear and anxiety represented significant aspects of this event. In class, it was not uncommon to hear students expressing their fear of public speaking. While some asked questions, such as 'do we have to present in front of everyone?" or "do we have to come to the front of the class to make our presentations?', others asked the teacher for advice regarding how to handle stage fright. In students' reflections, fear and anxiety were mostly associated with common fears of public speaking which concerned students because of the impact it could play on their performance. One of the students, for example, described how stress and anxiety impacted her:

$$
\text { أننا أعاني جدا من الإلقاء أمام الجمهور و أحاول دائما التغلب على هذا الثي لأنني عندما أتونر أفقد تركيزي و }
$$

I really suffer because of having to present in front of an audience and I always try to overcome this because when I get stressed out, I lose my focus and feel confused

While some students seemed to have accepted the inevitability of such struggle, their negative feelings extended beyond being confused to other aspects of this event. Students' familiarity with each other, for example, affected these feelings. Most of the reflections written after the first task associated feelings of nervousness, anxiety and stress with the fact that it took place during the second week of the semester when students were not yet familiar with each other or the teacher. According to one of the students,

I felt nervous a little bit because it's the first time and I didn't know the girls and the teacher

These feelings subsided slightly with the second and third task as students' knowledge of each other improved.

Time represented another significant factor in this issue. Many students complained in class and in their reflections about the short time they had to prepare these presentations. One student described her experience with the second task in which they were given an extra day to prepare as

$$
\text { أفضل من التجربة الأولى، التونر كان أقل، كان يوجد وقت كافي للحفظ }
$$

better than the first task, the stress was less, there was enough time to learn it by heart

The extra time presented an invaluable opportunity to practice and rehearse her presentation which improved the overall assessment of her experience.

Concerns about performing badly in front of their teacher and classmates represented another major factor impacting students' feelings of fear and anxiety. One student listed the challenges she faced during the second task which included

$$
\begin{aligned}
& \text { تكر ار رهبة المسرح و الخوف من الوقوع في أخطاء النطق أمام الجميع. الخوف من عدم فهم الجميع للوظيفة } \\
& \text { و ذكر معلومات قليلة و غير كافية لهذه الوظليفة الوفية }
\end{aligned}
$$


repeated stage fright and fear of making mistakes in pronunciation in front of everyone, fear that not everybody would understand the job and fear of mentioning too little information that is not enough for this job

These concerns, however, moved beyond common and expected concerns about grades and assessment.

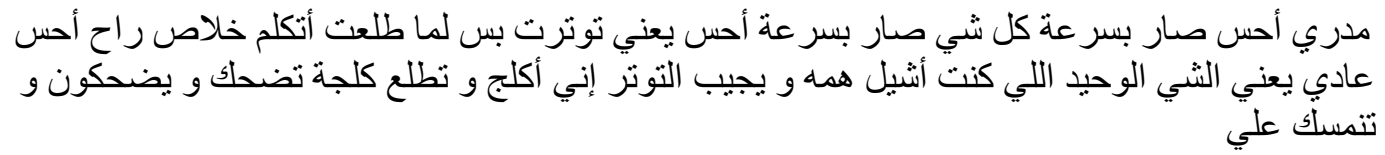

I don't know I feel it happened quickly everything happened quickly I feel, I mean I got stressed, but when I went up to talk, it went away, I felt OK, I feel the only thing that I worry about and stresses me out is me mumbling and I would say something that does not make sense and they would laugh at me and then they would hold it against me

Although attaining high grades and positive feedback from their teacher was important for students, many students were equally concerned about the image and status they created for themselves in this community every time they stood to present. These fears, however, became less dominant in students' reflections after the third task as some students appreciated the opportunity to present remotely without having to face their classmates in class. As most students generally described presenting in an online platform as less stressful, few talked about how they missed the encouragement and support of their classmates. Although it was true that their earlier face-to-face presentations were associated with common fears of public speaking, it was the third online presentation which brought to students' attention other aspects of their experiences beyond these negative feelings.

\subsection{Gains and losses}

Another significant theme in students' accounts appeared in how they perceived the impact of these presentations on their language learning and academic development. Some students described these presentations as useful and beneficial while others expressed a more negative view of these presentations. For some, the presentations were appreciated because they helped them to learn new vocabulary, organize information, improve their pronunciation and develop presentational skills. One student pointed out after her third presentation that

$$
\text { ونت أشعر بضعفي التام في اللغة لكن الآن أثنعر بالتطور أفهم أشرح و أقدر على الحفظو تعلم كلمات جديدة }
$$

I used to feel I was completely weak in the language, but now I feel I developed: I understand, I explain, and I can learn by heart new words and the experience was enjoyable.

Few also valued the opportunity this event provided for them to face and address their fears of public speaking.

It was good a little bit for me ...... regardless of how many times I felt nervous and spoke wrong but I'm proud of myself because I did it 
Students also wrote about developing new learning strategies that helped them to address the tasks' requirements and expectations. They particularly appeared to appreciate the benefits of practising and rehearsing their presentations individually and with their classmates. According to one student, recording her rehearsal a few times

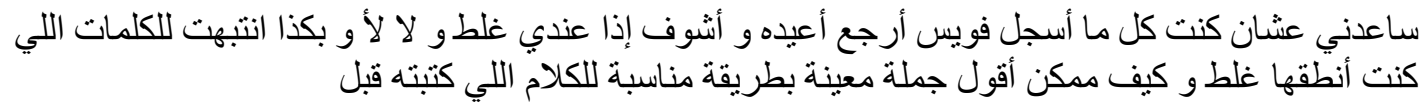
helped me because every time I recorded it, I listened to it to see if I made any mistakes or not, and so I paid attention to the words I was saying in a wrong way and how it was possible for me to say a specific sentence in a way suitable for the talk that I wrote before

While students' practice with classmates allowed them to give useful feedback to each other, recording their attempts developed their ability to recognize their weaknesses and work to address them.

Yet, that positive view and appreciation were not shared among all the students. Many described more negative views which were related to a variety of issues. For example, while most of them were able to bring in supporting materials, such as audios, videos and still images, few complained about their inability to prepare visuals that they were satisfied with because of the limited time they had, the strict demands and expectations that shaped these presentations and their need to focus on constructing their speech. Although some students did not seem to show any interests in supporting their presentations with extra materials, others complained in class about wishing to have been able to provide special visuals, make impressive collages or even create digital stories through which they could support their speech with impressive visuals.

Negative feelings among students extended to how engaging with these presentations impacted their views of themselves. Many students struggled with their negative views of their abilities and their image among their classmates which were brought to surface with every presentation.

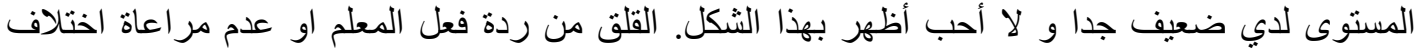

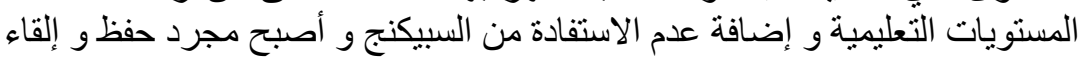

My level is really weak and I don't like appearing like that. Worrying about the teacher's reaction without putting in mind the differences in educational levels and in addition not benefiting from the speaking and it became just memorization and presenting

These struggles and inner doubts did not only affect their feelings towards their participation in this event, but also reduced it from preparing an oral presentation on a specific topic to just giving a pre-prepared recitation. They also brought to light students' awareness of the gap that separated them from other students who appeared to be more competent and their fear that such gap will not be put into consideration by the teacher. Despite providing students with an opportunity to work on their language, these presentations additionally appeared to serve as a reminder of their language current abilities. 
Ironically, these negative views were not uncommon among students and they were not confined to those struggling with language use. One learner explained in her account after the first task that the language was not something she worried much about while participating in this event. It was rather her fear of public speaking that dominated her memories as she recalled her presentations in the past.

I've tried it before twice. I thought that I was good but actually it's not at all. My teacher told me that I have to practice more and I tried. I suffer from social dread! I really feel uncomfortable when I just stand on the stage. EXTRA NERVOUS ( من رأيي مو كل الشخصيات يناسبها ذا الموضوع ). To be honest, I'm struggling with this.

The Arabic sentence in the student's writing can be translated as in my opinion, this thing (oral presentation) is not suitable for all personalities

For this learner, the presentation brought to her mind the past, unhappy memories of a previous presentation in which her performance was badly affected by her anxiety and fear despite having excellent language skills. She listened to her teacher's advice to practice and prepare herself for the task. Yet, her attitude towards this event did not change as her view of this experience was dominated by her overwhelming anxiety about speaking in front of others which she could not escape.

\section{Discussion}

This study investigated a literacy event in an EFL classroom in which students were required to give short oral presentations. Despite the short nature of these presentations, a number of significant issues were highlighted in the collected data. Students' reflections in specific drew attention to the gap between the promoted aim of these presentations and the practices that learners engaged with and the impact of this gap on learners' views of themselves and their investment in classroom activities. Although this academic event aimed at developing vital skills among university students, it did not always seem to be successful in maximizing this aim among students. Students described a number of practices that shaped how they engaged with these presentations. Some of these practices appeared to marginalize some students who talked about their struggle with different challenges, such as time, topic choice and feelings of fear and anxiety. These issues created considerable challenges to the extent that it transformed the event for some from an opportunity to develop their speaking to almost a test of their ability to catch up and recite a previously-made text in front of their classmates regardless of how that text was prepared.

In relation to topic choice, students' reflections highlighted the marginalizing impact that one-size-fits-all policies and unified requirements and expectations in academic events can create for students. While these presentations appeared to offer a promise for students to develop their speaking skill and speak about topics that mattered to them, not all the students were equally given these opportunities. Their topics, for example, were mediated by a number of factors, such as how quick they were to pick a topic, how good their language was to discuss challenging ideas and how willing they were to take the risk of offering repeated information in their presentations. Anxiety was also a significant aspect in students' reflections. In addition to the expected fears associated with public speaking, other factors intensified these feelings, including their familiarity with other members in their community and their fear of reflecting a negative image among their classmates. 
These issues had the ability to "enable or constrain the range of identities that language learners can negotiate in their classrooms and communities" (Norton, 2013, p. 49). They shaped how students engaged with the practices, expectations and requirements in this event in which challenges moved beyond grades and assessment. Their impact appeared in the decisions that students took to participate in this event and maintain the identity of a successful language learner; a learner who was able to prepare and make an oral presentation in English in a way that demonstrated competence and proficiency. Consider, for example, students' use of their local language. Though it did not seem to enhance the development of their speaking skill in English, it functioned as an effective coping strategy which facilitated learners' ability to engage with the requirements of this event while working within a demanding timeframe, especially for those struggling with English language use. It, thus, allowed many to survive the demanding nature of this event and paved the way for learners to reframe their struggles and work to attain a more powerful identity, i.e. the identity of a language learner who was able to competently present in English (Norton, 2019).

As further investigation is needed to examine the complex relation between learners' engagement with literacy events and improvement of the speaking skill in EFL classes, it is important for academic research to examine a variety of literacy events in tertiary education and explore the impact that social context has on developing learners' language and identity. Such examination is important to recognize and address problematic issues while working to empower learners and pave the way for them to embrace more powerful identity positions as language users that allow them to participate more effectively in language classes. As Hyland (2015) puts it,

contemporary perspectives see identity as part of a social and collective endeavour created through participation in our social groups and the ways we are linked to situations, to relationships, and to the rhetorical positions we adopt in our routine interactions with others. (p. 36)

There is an urgent need for more in-depth examination of the complexity of the social nature of language learning and how learners perceive their experiences in language classrooms. This is especially important to move beyond commonly dominant calls in this context that tend to hold teachers who are often tied down by "the limitations of time and the obligation to finish certain materials" as the major factor that determines success and failure in language education (DaifAllah \& Khan, 2016, p. 119). Pedagogical plans should take into consideration the larger social context that surrounds language learning because success in language classroom represents "a process in which everybody is involved to achieve successful outcomes" (Gaffas, 2019, p. 11). Issues, such as variation of levels among language learners in class, academic and pedagogical expectations, local language use and personal tendencies should be taken into consideration when examining the situated nature of learning. This is especially important to improve pedagogical decisions, empower language learners and enhance their learning experiences.

\section{Conclusion}

This article describes an ethnographically-oriented case study that aims to explore how Saudi female undergraduates engage with oral presentations in an EFL classroom. Relying on datacollection techniques, such as reflections written by learners, observational fieldnotes, research 
journal and informal conversations, this study highlights some of the social practices that underlie how these students engage with oral presentations while preparing and making their presentations. Furthermore, the study sheds light on some of the challenges that students face, how they address these challenges and the impact of these challenges on students and their views of themselves and language learning. Despite the exploratory and small scall nature of this study, this case study provides a glimpse of some of the challenges that surround language teaching and learning in EFL classrooms. As this study explores some aspects of language learning in tertiary education among undergraduates in relation to the development of speaking-related skills in English, it draws attention to the need to create legitimate space in academic research to explore learners' voices, views and feelings in different literacy events through qualitative methods which bring to surface hidden aspects of learners' experiences that may not be easily accessible otherwise. In contrast to the considerable focus on quantitative methods in academic research in language classrooms, this study attempts to provide in-depth investigation of significant aspects of the situated nature of learning in this context. Such aspects can be used to inform educational practices and pave the way for better pedagogical plans.

\section{About the Author}

Dr. Noura Ali Alghamdi is an assistant professor at the English Language Institute, University of Jeddah, Jeddah, Saudi Arabia. Her research interests include qualitative research methodology, literacy studies, multimodality, identity and computer assisted language learning. ORCid: https://orcid.org/0000-0002-9294-1443

\section{References}

Ababneh, I. (2016). Comparative Arabic and English literacy: A study of female university students' practices in Saudi Arabia. International Journal of Applied Linguistics and English Literature, 5(1), 1-7. doi:10.7575/aiac.ijalel.v.5n.1p.1

Abker, I.A. A. (2020). Difficulties in pronouncing English morphemes among Saudi EFL students at Albaha university. A case study in Almandag. Arab World English Journal, 11(2) 395-410. DOI: https://dx.doi.org/10.24093/awej/vol11no2.27

Alghamdi, O. S. (2015). Satisfaction of preparatory year students with university services. World Journal of Education, 5(5), 117-129. doi:10.5430/wje.v5n5p117

Al-Khotaba, H.H.A., Alkhataba, E. H. A., Abdul-Hamid, S., \& Bashir, I. (2019). Foreign language speaking anxiety: A psycholinguistic barrier affecting speaking achievement of Saudi EFL learners. Arab World English Journal, 10(4), 313- 329. DOI: https://dx.doi.org/10.24093/awej/vol10no4.23

Al-Mohanna, A. (2011). Developing English learners' listening-speaking skills interactively: An analytic study in the Saudi Arabian context. International Journal of Arts \& Sciences, 4(10), 77-105.

Alqahtani, M. (2015). Saudi students' willingness to communicate and success in learning English as a foreign language. Journal of Language Teaching and Research, 6(6), 1195 1205.

Alrasheedi, S. (2020). Investigation of factors influencing speaking performance of Saudi EFL learners. Arab World English Journal, 11(4) 66-77. DOI: https://dx.doi.org/10.24093/awej/vol11no4.5 
Bailey, K. (1991). Diary studies of classroom language learning: The doubting game and the believing game. In: E. Sadtono (Ed.), Language acquisition and the second/foreign language classroom (pp. 60-102). Singapore: SEAMEO.

Barnawi, O. Z., \& Phan, L. H. (2015). From western TESOL classrooms to home practice: A case study with two 'privileged' Saudi teachers. Critical Studies in Education, 56(2), 259-276. doi:10.1080/17508487.2014.951949

Barton, D. (1994). An introduction to the ecology of written language. Oxford: Blackwell.

Barton, D., \& Hamilton, M. (1998). Local literacies: Reading and writing in one community. London: Routledge.

Daif-Allah, A. S., \& Khan, M. I. (2016). The impact of open discussion sessions on enhancing the oral communicative abilities of Saudi English language majors at Buraydah Community College. English Language Teaching, 9(6), 108-122. doi:http://dx.doi.org/10.5539/elt.v9n6p108

Eissa, H. M. S. (2019). Pedagogic effectiveness of digital storytelling in improving speaking skills of Saudi EFL learners. Arab World English Journal, 10(1) 127-138. DOI: https://dx.doi.org/10.24093/awej/vol10no1.12

Gaffas, Z. M. (2019). Students' perceptions of the impact of EGP and ESP courses on their English language development: Voices from Saudi Arabia. Journal of English for Academic Purposes, 42, 1-13. https://doi.org/10.1016/j.jeap.2019.100797

Heath, S. B. (1983). Ways with words: Language, life and work in communities and classrooms. New York: Cambridge University Press.

Hyland, K. (2009). Academic discourse. London: Continuum.

Hyland, K. (2015). Genre, discipline and identity. Journal of English for Academic Purposes, 19, 32-43. doi:http://dx.doi.org/10.1016/j.jeap.2015.02.005

Javid, C. Z., Al-Asmari, A. R., \& Farooq, U. (2012). Saudi undergraduates' motivational orientations towards English language learning along gender and university major lines: A comparative study. European Journal of Social Sciences, 27(2), 283-300.

Lillis, T., \& Scott, M. (2008). Defining academic literacies research: Issues of epistemology, ideology and strategy. Journal of Applied Linguistics, 4(1), 5-32. doi:10.1558/japl.v4i1.5

Mahboob, A., \& Elyas, T. (2014). English in the kingdom of Saudi Arabia. World Englishes, 33(1), 128-142. doi:10.1111/weng.12073

Matusiak, K. K. (2013). Image and multimedia resources in an academic environment: A qualitative study of students' experiences and literacy practices. Journal of the American Society for Information Science and Technology, 64(8), 1577-1589. doi:10.1002/asi.22870

Morita, N. (2000). Discourse socialization through oral classroom activities in a TESL graduate program. TESOL Quarterly, 34(2), 279-310.

Mousawa, D. T., \& Elyas, T. (2015). Presentation as employability soft skill to ESP learners in the English Language Institute at King Abdulaziz University. Journal of Language Teaching and Research, 6(5), 1058-1062. doi:http://dx.doi.org.ezproxy.lancs.ac.uk/10.17507/jltr.0605.19

Nazim, M., \& Hazarika, Z. (2017). Efficacy of ESP in EFL context: A case study of Saudi Arabia. Arab World English Journal, 8(1), 145-164. 
Norton, B. (2013). Identity and language learning: Extending the conversation (2nd ed.). Bristol, UK: Multilingual Matters.

Norton, B. (2019). Identity and language learning: A 2019 retrospective account. The Canadian Modern Language Review / La revue canadienne des langues vivantes, 75(4), 299307.https://doi.org/10.3138/cmlr.2019-0287

Nunan, D. (1992). Research methods in language learning. Cambridge, UK: Cambridge University Press

Oxford, Rebecca L. (1990). Language learning strategies: What every teachers should know. Boston: Heinle \& Heinle Publishers

Pahl, K., \& Rowsell, J. (2012). Literacy and education: Understanding the new literacy studies in the classroom (2nd ed.). London: Sage Publications Ltd.

Rafada, S. H.\& Madini, A. A. (2017). Effective solutions for reducing Saudi learners' speaking anxiety in EFL classrooms. Arab World English Journal, 8(2), 308-322. DOI: https://dx.doi.org/10.24093/awej/vol8no2.22

Soomro, A. F., \& Farooq, M. U. (2018). EFL learners' attitude towards developing speaking skills at the University of Taif, Saudi Arabia. International Journal of English Linguistics, 8(3), 318-327. https://doi.org/10.5539/ijel.v8n3p318

Street, B. V. (1984). Literacy in theory and practice. New York: Cambridge University Press.

Thomas, G. (2011). How to do your case study: A guide for students and researchers. London: Sage Publications.

Zareva, A. (2011). 'And so that was it': Linking adverbials in student academic presentations. RELC Journal, 42(1), 5-15. doi:10.1177/0033688210390664 